\title{
Badanie przewidywalności szkody zgodnie z art. 74 zd. 2 Konwencji Narodów Zjednoczonych o umowach międzynarodowej sprzedaży towarów (CISC)
}

\begin{abstract}
Contractual liability for damages is not limitless, which is also reflected in provisions of United Nations Convention on Contracts for the Internatiownal Sale of Goods (CISG). Limitation of liability can be introduced in several ways; in CISG Convention this was achieved by limiting the liability to foreseeable damages. In Polish scholarship this issue has received only minimal attention. The author of the contribution focuses on the interpretation of Art. 74 second sentence of the CISG. The aim of the contribution is to elaborate on key normative elements affecting the proper evaluation of the foreseeability and to propose a step-by-step method (scheme) of evaluating the foreseeability of damage that - in the author's opinion - might ensure that such an exact and thorough evaluation according to the aforementioned provision. The author focuses primarily on the relevant time and subject of foreseeability, the perspective that ought to be taken into account, the factors affecting the foreseeability (will of the parties, binding practices and usages, knowledge of the party, as well as on the distinction between the objective foreseeability of damage (which refers to the damage that the party in breach ought to have foreseen) and the subjective foreseeability of damage (which refers to the damage that the party in breach had actually foreseen).
\end{abstract}

Keywords: Vienna Convention from 1980 - CISG - International Sale of Goods - Liability for damages - Foreseeability of damage - Methods of limiting the liability for damages

a) Mgr, Uniwersytet im. Adama Mickiewicza w Poznaniu. 
Podstawowym celem odszkodowania jest przywrócenie sytuacji, w jakiej poszkodowany znalazłby się, gdyby umowa została prawidłowo wykonana - sformułowana w ten sposób zasada pełnej kompensacji szkody obowiązuje w większości systemów prawnych ${ }^{1}$, nie ma ona jednak charakteru absolutnego ${ }^{2}$. Zasadzie pełnej kompensacji szkody przeciwstawiane jest ograniczenie odpowiedzialności odszkodowawczej w wyjątkowych sytuacjach ${ }^{3}$; za konieczne uznaje się ograniczenie odpowiedzialności odszkodowawczej za ponadprzeciętnie wysokie, względnie niespodziewanie wysokie, szkody ${ }^{4}$. Ograniczenie to można uzyskać na kilka sposobów, nazywanych „metodami ograniczania odpowiedzialności odszkodowawczej" (ang. methods of limiting the liability for damages ${ }^{5}$ ). W prawie polskim wprowadzono ograniczenie odpowiedzialności odszkodowawczej do szkody pozostającej $\mathrm{w}$ adekwatnym związku przyczynowym $\mathrm{z}$ określonym zachowaniem (art. 361 Kodeksu cywilnego ${ }^{6}$ ). W wielu innych systemach prawnych funkcje te spełnia ograniczenie odpowiedzialności odszkodowawczej do szkody przewidywalnej.

W niniejszym artykule podjęte zostaną rozważania dotyczące ograniczenia odpowiedzialności odszkodowawczej do szkody przewidywalnej, zgodnie z art. 74 zd. 2 Konwencji wiedeńskiej z dnia 11 kwietnia

1 J. Gotanda [Sprawozdawca], CISG advisory council opinion no. 6: Cal ulation of Damages under CISG Article 74, Adopted by the CISG-AC at its Spring 2006 meeting in Stockholm, Sweden, 2006, http://cisgw3.law.pace.edu/cisg/CISG-AC-op6. html, pkt 1.2 .

${ }^{2}$ A. Koch, Zwiazek przyczynowy jako podstawa odpowiedzialności odszkodowawczej $w$ prawie cywilnym, Państwowe Wydawnictwo Naukowe, Warszawa, 1975, s. 82 i tam powołane.

${ }^{3}$ A. Keil, Die Haftungsbefreiung des Schuldners im UN-Kaufrecht im Vergleich mit dem deutschen und US-amerikanischen Recht, P. Lang, Köln, 1994, s. 5; G.H. Treitel, Remedies for Breach of Contract. A comparative account, Clarendon Press, Oxford University Press, Oxford, 1988, s. 143; E. Rabel, Das Recht des Warenkaufs. Eine rechtsvergleichende Darstellung 1. Band, Walter de Gruyter \& Co., Berlin, 1964, s. 474 .

${ }^{4}$ A. Koch, Zwiazek..., s. 82; E. Rabel, Das Recht..., s. 474.

${ }_{5}$ Zob. D. Saidov, Methods of Limiting Damages under the Vienna Convention on Contracts for the International Sale of Goods, „Pace International Law Review” 2002, vol. 14 , no. 2 , s. 307.

Enumeracja metod ograniczania odpowiedzialności odszkodowawczej za zbyt wysokie szkody i ich analiza: E. Rabel, Das Recht..., s. 474 i n. Wspomniany autor wskazuje 4 sposoby - ograniczenie do szkody przewidywalnej, ograniczenie odpowiedzialności za szkodę pośrednią, uzależnienie uzyskania pełnego odszkodowania od stopnia winy oraz ograniczenie odszkodowania do szkód pozostających w adekwatnym związku przyczynowym z działaniem albo zaniechaniem.

${ }^{6}$ Ustawa z dnia 23 kwietnia 1964 r. - Kodeks cywilny, Dz.U. 1964, nr 16, poz. 93 ze zm. 
1980 r. ${ }^{7}$ [dalej: Konwencja wiedeńska lub CISG], której stroną jest Polska, podobnie jak obecnie ponad 90 innych państw ${ }^{8}$. Zgodnie z art. 74 zd. 2 CISG, odszkodowanie nie może przewyższać straty, którą strona naruszająca przewidywała lub powinna była przewidywać w chwili zawarcia umowy w świetle okoliczności, które znała lub powinna była znać jako możliwy rezultat naruszenia umowy.

„Kryterium przewidywalności” przywołane zostało w kilku przepisach CISG; przewidywalność uszczerbku jest przesłanką uznania naruszenia umowy za istotne (art. 25 CISG); strona może zostać zwolniona $\mathrm{z}$ odpowiedzialności przez wykazanie wystąpienia nieprzewidywalnej przeszkody w wykonaniu zobowiązania (art. 79 CISG). W niniejszym opracowaniu przedstawiono jedynie rozważania na temat przewidywalności szkody zgodnie z art. $74 \mathrm{zd} .2$ CISG.

Celem artykułu jest omówienie kluczowych zagadnień związanych $\mathrm{z}$ badaniem przewidywalności szkody oraz zaproponowanie sposobu badania przewidywalności szkody.

\section{Geneza i ratio legis przewidywalności szkody}

Ograniczenie do szkody przewidywalnej nie jest nową metodą ograniczenia odpowiedzialności odszkodowawczej; koncepcja przewidywalności szkody zainspirowana została rozwiązaniami prawa rzymskiego ${ }^{9}$. Ograniczenie to zostało najpierw wprowadzone do francuskiego Code civil $^{10}$, a później do systemów prawnych Common law ${ }^{11}$. W dalszej ko-

${ }^{7}$ Konwencja Narodów Zjednoczonych o umowach międzynarodowej sprzedaży towarów, sporządzona w Wiedniu dnia 11 kwietnia 1980 r., Dz.U. 1997, nr 45, poz. 286.

${ }^{8}$ Państwa mają możliwość ratyfikowania poszczególnych części CISG. W niektórych państwach CISG nie weszło jeszcze w życie. Aktualny status CISG: https://uncitral. un.org/en/texts/salegoods/conventions/sale_of_goods/cisg/status [Dostęp: 27.11.2021 r.].

9 E. Rabel, Das Recht..., s. 475-477.

${ }^{10}$ W obecnej formie: Article 1231-3: „Le débiteur n'est tenu que des dommages et intérêts qui ont été prévus ou qui pouvaient être prévus lors de la conclusion du contrat, sauf lorsque l'inexécution est due à une faute lourde ou dolosive", https://www.legifrance. gouv.fr/affichCodeArticle.do?idArticle=LEGIARTI000032010127\&cidTexte=LEGITEX T000006070721\&dateTexte=20161001 [Dostęp: 27.11.2021 r.].

${ }^{11} \mathrm{~W}$ Common law przewidywalność została ustanowiona przez precedens w sprawie Hadley v. Baxendale [Hadley v. Baxendale, 156 Eng. Rep. 146, Ex. Ch. 1854]: „the damages which the other party ought to receive in respect of such breach of contract should be such as may fairly and reasonably be considered either arising naturally, i.e., according to the usual course of things, from such breach of contract itself, or such as may reasonably 
lejności - wzorując się na prawie francuskim i Common law - ograniczenie do szkody przewidywalnej wprowadzone zostało do Konwencji haskiej z 1964 r. ${ }^{12}$, CISG, Principles of European Contract Law $(\mathrm{PECL})^{13}$ i UNIDROIT Principles ${ }^{14}$.

Niedopuszczalne jest przyjęcie, że ograniczenie do szkody przewidywalnej funkcjonuje tak samo we wszystkich systemach prawnych i aktach międzynarodowych ${ }^{15}$; niewłaściwe jest również powoływanie się na

be supposed to have been in the contemplation of both parties, at the time they made the contract, as the probable result of the breach of it".

Szczegółowy opis historii tej koncepcji przedstawili F. Ferrari, Comparative Ruminations on the Foreseeability of Damages in Contract Law, „Louisiana Law Review” 1993, vol. 53, no. 4; J. Napierała, Odpowiedzialność eksportera i importera za naruszenie umowy międzynarodowej sprzedaży towarów, ABC, Warszawa, 1998, s. 168-170.

${ }_{12}$ Convention relating to a Uniform Law on the International Sale of Goods of 1964, https://www.unidroit.org/instruments/international-sales/international-salesulis-1964 [dalej: ULIS], Art. 82: „Where the contract is not avoided, damages for a breach of contract by one party shall consist of a sum equal to the loss, including loss of profit, suffered by the other party. Such damages shall not exceed the loss which the party in breach ought to have foreseen at the time of the conclusion of the contract, in the light of the facts and matters which then were known or ought to have been known to him, as a possible consequence of the breach of the contract”. Konwencja ULIS to bezpośredni „poprzednik” CISG.

„CISG Article 74 was taken from and is, for all practical purposes, substantively identical to Article 82 of the 1964 Hague Uniform International Sales Law. This is important because it opens up to researchers case law and commentaries on ULIS Article 82 (of which there are many), as well as case law and commentaries on CISG Article 74". E. Schneider, Measuring Damages under the CISG - Article 74 of the United Nations Convention on Contracts for the International Sale of Goods, „Pace International Law Review" 1997, vol. 9, no. 1, s. 224-225. Zob. także J. Honnold, Documentary history of the uniform law for international sales: the studies, deliberations, and decisions that led to the 1980 United Nations Convention with introductions and explanations, Kluwer Law and Taxation Publishers, Deventer, 1989, s. 6. Biorąc pod uwage powyższe, w niniejszym artykule przytaczane są także orzecznictwo i głosy doktryny odwołujące się do konwencji ULIS.

${ }_{13}$ Principles of European Contract Law, Article 9:503: „The non-performing party is liable only for loss which it foresaw or could reasonably have foreseen at the time of conclusion of the contract as a likely result of its non-performance, unless the nonperformance was intentional or grossly negligent", https://www.trans-lex.org/400200/_ pecl/\#head_147 [Dostęp: 27.11.2021 r.].

${ }^{14}$ UNIDROIT Principles, Article 7.4.4: „The non-performing party is liable only for harm which it foresaw or could reasonably have foreseen at the time of the conclusion of the contract as being likely to result from its non-performance", https://www.unidroit. org/instruments/commercial-contracts/unidroit-principles-2016 [Dostęp: 27.11.2021 r.].

${ }_{15}$ Zob. I. Schwenzer, in: Kommentar zum UN-Kaufrecht (CISG), Hrsg. P. Schlechtriem, I. Schwenzer, U.G. Schroeter, C.H. Beck, München, 2019, s. 1256.

Dokładna analiza przewidywalności szkody w innych systemach prawnych G.H. Treitel, Remedies..., s. 150-162. 
orzecznictwo dotyczące przewidywalności szkody w innych systemach prawnych ${ }^{16}$. Nie oznacza to, że podobieństwa nie istnieją — doświadczenie w interpretowaniu wymogu przewidywalności szkody w myśl przepisów innego systemu prawnego może być pomocne, konieczna jest jednak świadomość co do podstawowych różnic pomiędzy poszczególnymi rozwiązaniami ${ }^{17}$. Pomimo pewnych podobieństw, niedopuszczalne jest też uznanie, że ograniczenie do szkody pozostającej w adekwatnym związku przyczynowym w praktyce prowadzić będzie do takich samych rezultatów, jak ograniczenie do szkody przewidywalnej ${ }^{18}$. Ograniczenie odpowiedzialności odszkodowawczej do szkody przewidywalnej ma na celu wyłączenie albo zmniejszenie odszkodowania za nietypowo wysokie szkody, których dłużnik nie musiał się spodziewać ${ }^{19}$. Ograniczenie to zostało wprowadzone do CISG, aby zmusić strony do kompleksowej analizy ryzyka związanego z zawarciem określonej transakcji ${ }^{20}$. Ma ono również wpływać na sposób współpracy stron, np. przez wzajemne szczegółowe informowanie się o okolicznościach danej transakcji ${ }^{21}$. Dobrze poinformo-

${ }^{16}$ Błędnie dokonano tego w: Orzeczenie Federal District Court [New York] (USA), 23.08.2006 (TeeVee Tunes, Inc. et al v. Gerhard Schubert GmbH), http://cisgw3.law. pace.edu/cases/060823u1.html [Dostęp: 27.11.2021 r.]: „The foreseeability requirement, the Second Circuit has explained, is identical to the well-known rule of Hadley v. Baxendale, 156 Eng. Rep. 145 (Ct.Exch.1854), such that relevant interpretations of that rule can guide the Court's reasoning regarding proper damages".

Wyjątkiem jest jednak Konwencja haska z 1964 r. (por. przyp. 12) — orzeczenia dotyczące przewidywalności szkody w Konwencji haskiej mogą być pomocniczo użyte jako wskazówka interpretacyjna przepisów CISG, w tym art. 74 zd. 2 CISG.

17 Zob. J. Honnold, On the road to unification of the law of sales, „Forum international” 1984, no. 2, s. 11: „What is needed is a bit of hesitation, to consider whether the familiar domestic approach is typical of that of other legal systems - as a basis for considering whether the international rule may have made a choice or developed a nuanced intermediate position".

Por. przyp. 11, 13 i 14: np. we wszystkich przypadkach mowa jest o prawdopodobnym rezultacie naruszenia (likely, probable) — w CISG rezultat ma być możliwy (possible). PECL nakazuje stosować przewidywalność szkody, chyba że naruszenie było umyślne albo rażąco niedbałe.

18 J. Klatka, G. Żmij, w: Konwencja wiedeńska o umowach międzynarodowej sprzedaży towarów: komentarz, red. M. Pazdan, Zakamycze, Kraków, 2001, s. 615-616; P. Machnikowski, CISG in Polish case law, „Internationales Handelsrecht” 2018, Nr. 5, s. 183.

${ }^{19}$ H. Schönle, T. Koller, in: Kommentar zum UN-Kaufrecht: Übereinkommen der Vereinten Nationen über Verträge über den Internationalen Warenkauf (CISG), Hrsg. H. Honsell, Springer, Berlin, 2008, s. 1009; J. Napierała, Odpowiedzialność eksportera..., s. 172 .

${ }^{20}$ L. Vékás, The Foreseeability Doctrine in Contractual Damage Cases, „Acta Juridica Hungarica" 2002, vol. 43, no. 1-2, s. 162-163.

${ }^{21}$ Zob. Orzeczenie Oberster Gerichtshof (Austria), 4Ob208/12k, 15.01.2013, https:// www.ris.bka.gv.at/Dokument.wxe?Abfrage=Justiz\&Dokumentnummer=JJT_20130115_ 
wane strony mają możliwość prawidłowego przygotowania się do wykonania danej umowy i mogą zabezpieczyć się na wypadek jej naruszenia, np. przez wykupienie stosownego ubezpieczenia. Co więcej, strona uświadamiająca sobie zwiększone ryzyko związane z określoną umową może zażądać zmiany postanowień umownych (np. zwiększenia ceny) ${ }^{22}$. Celem jest także wyeliminowanie deficytów informacyjnych, aby strony mogły na transakcji jak najwięcej zyskaće ${ }^{23}$.

\section{Trudności związane z badaniem przewidywalności szkody}

„Jedną $\mathrm{z}$ istotnych przeszkód $\mathrm{w}$ rozwoju międzynarodowego handlu jest brak stabilności i pewności prawa, wynikający m.in. z niepewności co do tego, jakie prawo będzie ostatecznie stosowane przez strony umowy" ${ }^{24}$. Konwencja CISG przeszkody te miała zlikwidować; jak dotąd, udało się to tylko częściowo. Mimo że CISG obowiązuje już ponad 40 lat, jednolita wykładnia przepisów Konwencji nadal sprawia trudności. Podmioty prowadzące działalność międzynarodową wiedzą o tym,

OGH0002_0040OB00208_12K0000_000 [Dostęp: 27.11.2021 r.]: „Es gilt grundsätzlich ein objektiver Maßstab. Der Schuldner muss mit den Folgen rechnen, die eine verständige Person in seiner Lage angesichts der konkreten Fallumstände vorausgesehen hätte. $\mathrm{Ob}$ er selbst diese Voraussicht tatsächlich hatte, ist ebenso unerheblich wie ein mögliches Verschulden; allerdings kann die subjektive Risikoeinschätzung nicht ganz vernachlässigt werden: Weiß der Schuldner, dass eine Vertragsverletzung ungewöhnliche oder ungewöhnlich hohe Schäden auslösen würde, dann sind ihm auch diese Folgen zuzurechnen.

Der Termindruck der Klägerin war der Beklagten aus der Vorkorrespondenz hinlänglich bekannt. Dass im Fall der Nichterfüllung daher nicht nur Kosten für einen (teureren) Deckungskauf auftreten können, sondern mit einer dann erforderlichen forcierten Abwicklung sowie bei Unbrauchbarkeit einer früheren Teillieferung mit Anpassungskosten zu rechnen ist, liegt auf der Hand".

${ }_{22}$ Zob. L. Gama [Sprawozdawca], CISG Advisory Council Opinion No. 17 Limitation and Exclusion Clauses in CISG Contracts. Adopted by the CISG-AC following its 21st meeting in Bogotá, Colombia, on 16 October 2015, http://cisgac.com/opinion-17/ [Dostęp: 27.11.2021 r.], pkt 2.2.2 i n.

${ }_{23}$ T. Ackermann, Adäquanz und Vorhersehbarkeitsregel: ein transparenter methodischer Ansatz, dargestellt am Beispiel des schweizerischen Haftpflicht- und Vertragsrechts, des Wiener Kaufrechts und des schweizerischen Sozialversicherungsrechts, Haupt Verlag, Bern, 2001, s. 164; F. Faust, Die Vorhersehbarkeit des Schadens gemäß Art. 74 Satz 2 UN-Kaufrecht (CISG), Mohr Siebeck, Tübingen, 1996, s. 218.

24 J. Rajski, Jednolite prawo międzynarodowej sprzedaży towarów, „Przegląd Prawa Handlowego" 1996, nr 3, s. 6. 
z tego też względu czasami decydują się na wyłączenie zastosowania CISG.

Ograniczenie odpowiedzialności odszkodowawczej do szkody przewidywalnej ma olbrzymi potencjał w handlu międzynarodowym jako „domyślna metoda ograniczenia odpowiedzialności odszkodowawczej”"25. Nie można jednak zignorować faktu, że badanie przewidywalności szkody sprawia często problemy interpretacyjne, ograniczenie to zostało bowiem sformułowane przy użyciu zwrotów niedookreślonych; brak jest też jednoznacznych wytycznych, jak badać przewidywalność szkody. Takie sformułowanie art. 74 zd. 2 CISG było jednak zamierzone i ma - podobnie jak np. ograniczenie odpowiedzialności odszkodowawczej do szkody pozostającej w adekwatnym związku przyczynowym z naruszeniem umowy - pozostawić sędziemu swobodę decyzyjną. Jednakże, ze względu na elastyczny charakter ograniczenia do szkody przewidywalnej istnieje zagrożenie, że interpretacja przewidywalności szkody wiązać się będzie w niektórych przypadkach z arbitralnością orzeczeń. W praktyce orzeczniczej jednolita wykładnia art. 74 CISG i jednolita wykładnia przewidywalności szkody w dalszym ciągu stanowią problem ${ }^{26}$. Problematyczne jest także to, że sędziowie mogą odwołać się do przewidywalności rozumianej „ogólnie”, a więc przy odwołaniu się do ogólnoludzkich intuicji na temat przewidywalności zdarzeń, a nie w myśl przepisów CISG. Realne jest też niebezpieczeństwo, że każde państwo, względnie grupa państw, stworzy własną „wersję" przewidywalności szkody w myśl przepisów CISG ${ }^{27}$. Potencjalna arbitralność decyzji traktujących o przewidywalności szkody i przykłady orzeczeń zbyt „swobodnie” interpretujących art. $74 \mathrm{zd}$. 2 CISG nie są jednak dowodem na wadliwość samej koncepcji, a jedynie przejawem nieprawidłowej i niedbałej wykładni przepisów CISG.

Autor stoi na stanowisku, że ujednolicenie wykładni przewidywalności szkody w myśl art. 74 zd. 2 CISG może zostać osiągnięte m.in. przez stosowanie ujednoliconego sposobu (względnie metody) badania przewidywalności szkody, która zapewni, że badanie to opierać się będzie na normatywnych elementach wyznaczonych przez art. 74 zd. 2 CISG; metoda ta nie została jak dotąd przyjęta ${ }^{28}$.

${ }^{25}$ Zob. D. Saidov, The law of damages in international sales: the CISG and other international instruments, Hart Publishing, Oxford, Portland, 2008, s. 121-123.

${ }^{26}$ A. Ehlers, Establishing a Uniform Interpretation of the CISG: A Case Study of Article 74, „Nordic Journal of Commercial Law” 2013, no. 2, s. 22-32.

27 A. Ehlers, Establishing a Uniform Interpretation of the CISG: A Case Study of Article 74, „Nordic Journal of Commercial Law” 2013, no. 2, s. 22-32.

28 A. Ehlers, Establishing a Uniform Interpretation of the CISG: A Case Study of Article 74, „Nordic Journal of Commercial Law” 2013, no. 2, s. 22-32. 


\section{Badanie przewidywalności szkody}

\subsection{Wprowadzenie}

Ustrukturyzowanie sposobu badania przewidywalności szkody może ułatwić dokonanie szczegółowej analizy przewidywalności szkody. Zaproponowany sposób polega na wyróżnieniu etapów badania przewidywalności szkody. Badanie przewidywalności szkody nie ma prowadzić do przesądzania zawsze w ten sam sposób o szkodach tego samego rodzaju i wysokości ${ }^{29}$ chodzi jedynie o jednolitość metody, a nie o jednolitość rezultatu.

Rozważania podjęte $\mathrm{w}$ niniejszym artykule opierają się na dominującej $\mathrm{w}$ doktrynie normatywnej koncepcji przewidywalności szkody ${ }^{30}$ (stojącej w opozycji do koncepcji empirycznej ${ }^{31}$ ). Zgodnie z normatywną koncepcją, badając, czy szkoda była obiektywnie przewidywalna, odnieść należy się każdorazowo do konkretnej sytuacji, głównie uwzględniając takie elementy, jak np.: typ podmiotu, rentowność przedsiębiorstwa, cel umowy ${ }^{32}$. Zgodnie z koncepcją empiryczną, należy zignorować te kwe-

${ }^{29}$ D. Saidov, The law..., s. 121-22: „The law of damages, it seems, requires a balanced approach which would rely upon rules which would be sufficiently flexible to accommodate a variety of factual settings and, at the same time, would still have a discernible content. The foreseeability rule would appear to fit this description".

Por. uwagi w stosunku do art. 25 CISG B. Zeller, The Remedy of Fundamental Breach and the United Nations Convention on the International Sale of Goods (CISG) A Principle Lacking Certainty?, „Vindobona Journal of International Commercial Law \& Arbitration” 2007, vol. 11, no. 2, s. 235-236.

${ }^{30}$ Por. I. Schwenzer, in: Kommentar zum UN-Kaufrecht (CISG), Hrsg. P. Schlechtriem..., s. 1257; U. Huber, Der Uncitral-Entwurf Eines Übereinkommens über Internationale Warenkaufverträge, „Rabels Zeitschrift Für Ausländisches Und Internationales Privatrecht" 1979, vol. 43, Nr. 3, s. 469; J. Napierała, Odpowiedzialność eksportera..., s. 171; J. Klatka, G. Żmij, w: Konwencja..., s. 621; M. Karollus, UN-Kaufrecht: Eine Systematische Darstellung Für Studium und Praxis, Springer, Wien, New York, 1991, s. 217; Orzeczenie SA w Katowicach, V ACa 938/15, 21.07.2016, Legalis: 1501842; w odniesieniu do ULIS: H. Weitnauer, in: Kommentar Zum Einheitlichen Kaufrecht, Hrsg. H. Dölle, C.H. Beck, München, 1976 s. 543; H. Weitnauer, Nichtvoraussenhbarkeit Eines Schadens Nach Art. 82 S. 2 Des Einheitlichen Gesetzes Über Den Internationales Kauf Beweglichen Sachen, IPRax 1981, vol. 4, Nr. 1, s. 83.

${ }_{31}$ Zob. F. Faust: Die Vorhersehbarkeit..., s. 34, 273, 331.

${ }^{32}$ U. Huber, Der Uncitral-Entwurf..., s. 469; Orzeczenie Oberster Gerichtshof (Austria), 4Ob208/12k, 15.01.2013, https://www.ris.bka.gv.at/Dokument.wxe?Abfrage=Justiz\&Dokumentnummer=JJT_20130115_OGH0002_0040OB00208_12K0000_000 [Dostęp: 27.11.2021 r.]: „Die Voraussehbarkeit muss sich unter Berücksichtigung des Vertragszweckes - auf den Verlust beziehen, der mögliche Folge einer Vertragsverletzung sein kann". 
stie i kierować się matematycznie wyliczalną uśrednioną wysokością szkody ${ }^{33}$.

\subsection{Sposób badania przewidywalności szkody}

Relewantne jest zarówno to, co strona faktycznie przewidywała, jak i to, co powinna była przewidzieć - można więc mówić o przewidywalności obiektywnej i subiektywnej ${ }^{34}$. Badanie przewidywalności szkody należy podzielić na trzy etapy.

Pierwszy etap należy poprzedzić etapem wstępnym (kontrolnym), mającym na celu ustalenie, czy umowa nie reguluje jednoznacznie odpowiedzialności odszkodowawczej, sposobu naprawienia szkody, czy nie wyłącza zastosowania CISG, czy też nie modyfikuje w znacznym stopniu ograniczenia z art. 74 zd. 2 CISG - ze względu na postanowienia umowy, w niektórych przypadkach całkowicie zbędne będzie odwołanie się do przewidywalności szkody (wyczerpująca umowna regulacja odpowiedzialności odszkodowawczej jest jednak rzadkością ${ }^{35}$ ). Tylko w przypadku braku takich postanowień umownych możliwe będzie badanie przewidywalności szkody na podstawie zaproponowanej metody, w przeciwnym razie konieczne będzie rozstrzygnięcie kwestii na podstawie postanowień umowy; kierowanie się zaproponowanymi wskazówkami możliwe będzie jedynie mutatis mutandis.

Pierwszy etap polega na zawężeniu etapu badawczego przez sprecyzowanie określonego czasu, perspektywy i przedmiotu relewantnego zgodnie z art. $74 \mathrm{zd} .2$ CISG, według trzech podstawowych założeń: przewidywalność odnosi się do szkody (jej rodzaju i wysokości); przewidywalność szkody badana jest z perspektywy strony naruszającej umowę; moment, do którego szkoda powinna zostać przewidziana, wyznacza chwila zawarcia umowy.

W ramach drugiego etapu zbadać należy czynniki warunkujące przewidywalność szkody, czyli wiedzę strony, wolę stron umowy, wiążące praktyki i zwyczaje. Czynniki warunkujące przewidywalność szkody to elementy stanu faktycznego. Modyfikują one stosunek prawny między stronami; są „modyfikatorami” albo „zmiennymi”, prowadzącymi do tego, że przewidywalność w konkretnym przypadku różnić może się

${ }_{33}$ Por. F. Faust, Die Vorhersehbarkeit..., s. 34-35, 331.

${ }^{34}$ Zob. D. Saidov, Methods..., s. 341-342.

${ }^{35}$ F. Blase, Ph. Höttler, in: An international approach to the interpretation of the United Nations Convention on Contracts for the International Sale of Goods (1980) as uniform sales law, eds. J. Felemegas, Cambridge University Press, Cambridge, New York, 2007, s. 466. 
od „ogólnej przewidywalności szkody” albo tego, co jest „ogólnie przewidywalne”. Czynniki bada się przez pryzmat określonego przedmiotu przewidywalności, perspektywy i czasu.

Ostatecznie należy sprecyzować, czy szkoda (dokładnie określona co do rodzaju i wysokości) w danym czasie (dokładnie określonym momencie zawarcia umowy), z perspektywy dokładnie określonej osoby, ze względu na wiedzę strony, postanowienia umowne, wiążące praktyki i zwyczaje powinna była zostać przewidziana (obiektywna przewidywalność szkody), albo czy została przewidziana (subiektywna przewidywalność szkody).

Zgodnie z art. 74 zd. 2 CISG, aby zasądzić odszkodowanie za określoną szkodę, wystarczy ustalić albo przewidywalność obiektywną, albo subiektywną. Możliwe jest także, że szkoda będzie częściowo przewidywalna; albo raczej rodzaj szkody uznany zostanie za co do zasady przewidywalny, ale jej zakres - nie.

\section{Perspektywa, przedmiot i czas}

\subsection{Wprowadzenie}

W myśl art. 74 CISG znaczenie ma jedynie przewidywalność konkretnej szkody, z konkretnie określonej perspektywy i w konkretnie określonym czasie. Badanie przewidywalności szkody należy więc rozpocząć od rozstrzygnięcia tych trzech kwestii.

\subsection{Perspektywa}

Wiążąca jest perspektywa strony dopuszczającej się naruszenia $^{36}$. Nawet obiektywna przewidywalność jest, zgodnie z art. 74 zd. 2 CISG, relatywizowana ze względu na perspektywę osoby naruszającej umowę.

${ }^{36}$ M. Czarnecki, in: UN-Kaufrecht - CISG: Kommentar zum Übereinkommen der Vereinten Nationen über Verträge über den internationalen Warenkauf von 1980 - Unter Berücksichtigung der Schnittstellen zum internen Schweizer Recht, Hrsg. Ch. Brunner, Stämpfli Verlag, Bern, 2014, s. 621; Orzeczenie Oberster Gerichtshof (Austria), $7 \mathrm{Ob} \mathrm{301/01t,} \mathrm{14.01.2002,} \mathrm{http://www.unilex.info/case.cfm?pid=1 \& do=case \& id=858 \&}$ step=FullText [Dostęp: 27.11.2021 r.]. 
Szkoda musi być przewidywalna tylko z perspektywy strony naruszającej umowę, nie musi być ona przewidywalna dla obu stron kontraktu. Jest to jedna $\mathrm{z}$ podstawowych różnic pomiędzy przewidywalnością w myśl CISG a przewidywalnością w systemach Common law (Hadley v. Baxendale rule $\left.{ }^{37}\right)$. Nie stanowi to wielkiej różnicy $\mathrm{w}$ praktyce ${ }^{38}$, jednakże skupienie się tylko na perspektywie osoby naruszającej umowę pozwala na bardziej transparentną ocenę przewidywalności szkody jeżeli przewidywalność szkody badana będzie przez pryzmat tylko jednej osoby, to łatwiej będzie zdeterminować relewantne okoliczności, jej pozycję, typ kwalifikacji itp.

\subsection{Przedmiot}

Przewidywalność odnosi się do szkody stanowiącej damnum emergens i lucrum cessans, poniesionej w rezultacie naruszenia umowy. Dla strony naruszającej umowę przewidywalny musi być zarówno typ (względnie rodzaj) szkody, jak i jej zakres ${ }^{39}$. Chodzi jednak o przybliżoną wysokość szkody, a nie matematyczne jej wyliczenie ${ }^{40}$ — innymi słowy, strona musi być świadoma skali szkody, jaką może wyrządzić naruszeniem

${ }^{37}$ Porównanie przewidywalności szkody w CISG i Common law B. Zeller, Damages under the Convention on Contracts for the International Sale of Goods, Oceana Publications Inc, Oxford, 2018, s. 98 i n.

${ }_{38}$ Zob. A. Corbin, Corbin on Contracts. A Comprehensive Treatise on the Working Rules of Contract Law, 1964, vol. 5, s. 83.

${ }^{39}$ R. Herber, in: Internationales Kaufrecht: Kommentar zu dem Übereinkommen der Vereinten Nationen vom 11. April 1980 über Verträge über den Internationalen Warenkauf, Hrsg. R. Herber, B. Czerwenka, C.H. Beck, München, 1991, s. 333; Orzeczenie Multi-Member Court of First Instance of Athens (Grecja), 4505/2009 (Bullet-proof vest case), http://cisgw3.law.pace.edu/cases/094505gr.html [Dostęp: 27.11.2021 r.]; H. Schönle, T. Koller, in: Kommentar zum UN-Kaufrecht: Übereinkommen der Vereinten Nationen über Verträge über den Internationalen Warenkauf (CISG), Hrsg. H. Honsell..., s. 1010; B. Piltz: Internationales Kaufrecht: Das UN-Kaufrecht in Praxisorientierter Darstellung, C.H. Beck, München, 2008, s. 413; B. Zeller, Damages..., s. 104; V. Heuzé, La Vente Internationale de Marchandises: Droit Uniforme, L.G.D.J, Paris, 2000, s. 404; N. Schmidt-Ahrendts, M. Czarnecki, in: UN-Kaufrecht - CISG: Kommentar zum Übereinkommen der Vereinten Nationen über Verträge über den internationalen Warenkauf von 1980 - Unter Berücksichtigung der Schnittstellen zum internen Schweizer Recht, Hrsg. Ch. Brunner..., s. 622; Orzeczenie Commercial Court St. Gallen (Szwajcaria), 3.12.2002, http://cisgw3.law.pace.edu/cases/021203s1.html [Dostęp: 27.11.2021 r.].

Odmienne stanowisko T. Ackermann: Adäquanz..., s. 169; F. Faust: Die Vorhersehbarkeit..., s. 330 .

${ }^{40}$ Zob. Orzeczenie Oberster Gerichtshof (Austria), OGH 7ob 301/01t, 14.01.2002, http://www.unilex.info/case.cfm?pid=1\&do=case\&id=858\&step=FullText [Dostęp: 27.11. 2021 r.]. 
umowy. Bez znaczenia są kategorie szkód wyróżniane na podstawie innych porządków prawnych (np. direct damages, indirect/consequential damage ${ }^{41}$ ); jednak będą one mieć znaczenie wtedy, gdy do umowy wprowadzą je strony kontraktu ${ }^{42}$. Bez znaczenia pozostaje też przewidywalność naruszenia umowy ${ }^{43}$.

Jak obrazuje precedens dotyczący przewidywalności szkody w systemach Common law Victoria Laundry (Windsor) Ltd. v. Newman Industries $\mathrm{Ltd} .^{44}$, rozróżnienie pomiędzy przewidywalnością rodzaju szkody a przewidywalnością wysokości ma istotne znaczenie praktyczne. W sprawie tej niewykonanie umowy przez sprzedającego uniemożliwiło kupującemu wykonanie wyjątkowo lukratywnych dla niego zleceń. Sąd uznał co prawda, że szkoda związana z niemożnością prowadzenia działalności gospodarczej na skutek niewykonania umowy jest co do zasady przewidywalna (przewidywalny jest więc typ względnie rodzaj szkody),

${ }^{41}$ Orzeczenie Oberster Gerichtshof (Austria), 4Ob208/12k, 15.01.2013, https://www. ris.bka.gv.at/Dokument.wxe?Abfrage=Justiz\&Dokumentnummer=JJT_20130115_ OGH0002_0040OB00208_12K0000_000 [Dostęp: 27.11.2021 r.]: „Überdies ist für die Ersatzpflicht nach Art 74 CISG unmaßgeblich, ob die Vertragsverletzung einen unmittelbaren oder mittelbaren, direkten oder indirekten Schaden verursacht, solange dieser bei Vertragsabschluss vorhersehbar war".

Orzeczenie Oberster Gerichtshof (Austria), OGH 7ob 301/01t, 14.01.2002, http://www. unilex.info/case.cfm?pid=1\&do=case\&id=858\&step=FullText [Dostęp: 27.11 .2021 r.]: „Auch Mangelfolgeschäden sind, soweit es sich um Vermögensschäden handelt, wie bereits erwähnt, nach dem UN-Kaufrecht grundsätzlich ersatzfähig, wenn der eingetretene Schaden bei Vertragsschluss als hinreichend wahrscheinliche Folge erkannt werden konnte".

Dokładniejsze rozważania na temat direct i indirect damages E. Rabel, Das Recht..., s. $474-481$.

${ }^{42}$ Orzeczenie Federal District Court [Illinois] (USA), 29.01.2003, (Ajax Tool Works, Inc. v. Can-Eng Manufacturing Ltd.), http://www.cisg.law.pace.edu/cisg/wais/ db/cases2/030129u1.html [Dostęp: 27.11.2021 r.]: „It is undisputed that the parties' agreement states that, [Seller] shall not be liable for consequential damages”. As discussed above, such limited liability provision is enforceable under the CISG. Further, although Article 74 of the CISG provides for consequential damages, „such damages may not exceed the loss which the party in breach foresaw or ought to have foreseen at the time of the conclusion of the contract, in the light of the facts and matters of which he then knew or ought to have known, as a possible consequence of the breach of contract". CISG Art. 74. Because [buyer] did not address this point in its response memorandum, as best this court can tell, [buyer] has not introduced any evidence that the consequential damages sought were foreseeable to [seller]. For these reasons and because there are no facts disputed, summary judgment is granted as to consequential damages".

${ }^{43}$ U. Magnus, in: Wiener UN-Kaufrecht (CISG). J. von Staudingers Kommentar zum Bürgerlichen Gesetzbuch mit Einführungsgesetz und Nebengesetzen Wiener UN-Kaufrecht (CISG), Hrsg. U. Magnus, Sellier — de Gruyter, Berlin, 2018, s. 891; J. Napierała, Odpowiedzialność eksportera..., s. 170.

${ }^{44}$ Victoria Laundry (Windsor) Ltd. v. Newman Industries Ltd. [1949] 2 K.B 528. 
jednak nie sposób uznać, że przewidywalny był jej całkowity zakres, który przekraczał znacznie przeciętne zyski możliwe do wypracowania w tej branży w określonym czasie ${ }^{45}$.

Ze względu na to, że przewidywalny musi być typ (rodzaj) szkody i jej zakres rozstrzygnięcie o przewidywalności szkody może wiązać się z odrzuceniem w całości roszczenia odszkodowawczego za daną szkodę, albo jedynie z ograniczeniem wysokości przyznanego odszkodowania. Uznanie zakresu szkody za nieprzewidywalny nie powinno prowadzić automatycznie do odrzucenia całości roszczenia odszkodowawczego ${ }^{46}$. Odmienna interpretacja prowadziłaby do trudnych do zaaprobowania rezultatów. W znacznie korzystniejszej sytuacji znalazłby się bowiem podmiot, który doznał niewielkiej szkody w porównaniu z podmiotem doznającym szkody znacznych rozmiarów. Doszłoby do bezpodstawnego odrzucenia całości roszczenia odszkodowawczego w przypadku doznania szkody o nieprzewidywalnym zakresie, ale przewidywalnej co do zasady (ze względu na rodzaj szkody), natomiast w przypadku doznania szkody o mniejszej skali (gdzie wysokość szkody i jej typ są przewidywalne) poszkodowany otrzymałby całość odszkodowania.

\subsection{Czas}

Celem wprowadzenia ograniczenia odpowiedzialności odszkodowawczej do szkody przewidywalnej jest przede wszystkim umożliwienie stronie kalkulacji ryzyka jeszcze przed zawarciem umowy. Dlatego też szkoda musi być przewidywalna albo przewidywana w chwili zawierania umowy ${ }^{47}$. Bez znaczenia jest przekazanie informacji o potencjalnym ryzyku związanym z kontraktowaniem po zawarciu umowy ${ }^{48}$. Jest to jedna

${ }_{45}$ Opis na podstawie G.H. Treitel, Remedies..., s. 155.

${ }_{46}$ Orzeczenie SN (Polska) 20.01.2015, V CSK 254/14, http://www.sn.pl/orzecznictwo/ SitePages/Baza_orzeczen.aspx?ItemSID=17564-57a0abe2-a73c-441d-9691-b79a0c36be5c\&ListName=Örzeczenia3\&Sygnatura=V+CSK+254\%2f14 [Dostęp: 27.11.2021 r.]. Sąd, kierując się kryterium przewidywalności szkody, zasądził odszkodowanie pokrywające $20 \%$ szkody.

Zob. M. Durbas, Przewidywalność szkody jako przesłanka odpowiedzialności odszkodowawczej na gruncie Konwencji wiedeńskiej-glosa - V CSK 91/11, „Monitor Prawniczy" 2014, nr 5, s. 260-264.

${ }^{47}$ D. Saidov, Methods..., s. 339-341.

48 Orzeczenie Oberlandesgericht Bamberg (Niemcy) 13.01.1999, 3 U 83/98, http://www. unilex.info/case.cfm?pid=1\&do=case\&id=504\&step=FullText [Dostęp: 27.11 .2021 r.]: „Denn nach Art. 74 CISG hat die vertragsbrüchige Partei nur den Schaden zu ersetzen, den sie bei Vertragsabschluß als mögliche Folge der Vertragsverletzung vorausgesehen hat oder hätte voraussehen müssen. Eine erst nach Vertragsabschluß erlangte 
z podstawowych różnic pomiędzy ograniczeniem odpowiedzialności odszkodowawczej do szkody przewidywalnej a ograniczeniem odszkodowania do szkody pozostającej w adekwatnym związku przyczynowym z naruszeniem umowy - adekwatność należy oceniać, biorąc pod uwagę czas niewykonania albo nienależytego wykonania umowy ${ }^{49}$.

Czasu, w którym szkoda powinna była zostać przewidziana albo została przewidziana, nie należy mylić z czasem określania przewidywalności szkody, który zbieżny jest z czasem wyrokowania. Nie jest więc istotne to, co wiadome jest sędziemu w momencie wyrokowania, a jedynie to, czego powinna spodziewać się strona w momencie zawierania umowy. Artykuł 23 CISG precyzuje, że umowa jest zawarta z chwilą, gdy przyjęcie oferty stanie się skuteczne, zgodnie z postanowieniami konwencji.

Bez znaczenia są stan wiedzy i przewidywalność szkody po zawarciu umowy. Zachowanie stron po zawarciu umowy może jednak świadczyć o tym, co było dla nich przewidywalne jeszcze przed jej zawarciem. I tak, podjęcie określonych zabezpieczeń po zawarciu umowy może być dowodem na to, że określone ryzyko było już rozpoznane na etapie negocjacji. Wynikać to może również z korespondencji między stronami po zawarciu umowy ${ }^{50}$.

\section{Czynniki warunkujące przewidywalność szkody}

Czynniki warunkujące przewidywalność szkody to: wiedza strony naruszającej umowę, wola stron, wiążące praktyki oraz zwyczaje ${ }^{51}$. Czynniki bada się przez pryzmat określonego wcześniej przedmiotu przewidywalności, perspektywy i czasu - a więc według określonego momentu, $\mathrm{z}$ danej perspektywy oraz w stosunku do określonej szkody.

Kenntnis genügt nicht”. Orzeczenie Federal District Court [New York] (USA), 16.04.2008, (Macromex Srl. v. Globex International, Inc.), http://www.cisg.law.pace.edu/cisg/wais/db/ cases2/080416u1.html [Dostęp: 27.11.2021 r.].

${ }_{49}$ P. Sobolewski, w: Kodeks cywilny. Komentarz, red. K. Osajda, C.H. Beck, Warszawa, 2019, Komentarz do art. 361, nb. 20; wyr. SN z 15.11.2012 r., V CSK 541/11, Legalis: 577261.

${ }^{50}$ Zob. Orzeczenie Landgericht Kassel, 21.09.1995, 11 O 4261/94, http://www.cisgonline.ch/content/api/cisg/urteile/192.htm [Dostęp: 27.11.2021 r.]: „die maßgebenden Vertreter der Beklagten waren sich, wie der beiderseitige Schriftwechsel und insbesondere das Schreiben vom 14. Februar 1994 belegt, durchaus des korrespondierenden Geschäfts mit einem Endabnehmer und der hieran knüpfenden Gefahren und Chancen bewußt. Damit lag auf der Hand, daß jeder Verstoß gegen die eigene Lieferpflicht zu den in Rede stehenden Nachteilen führen konnte".

${ }^{51}$ Zob. D. Saidov, Methods..., s. 97-100; B. Zeller, Damages..., s. 104-109. 


\subsection{Wola stron, wiążące praktyki i zwyczaje}

Zarówno wola stron umowy, jak i wiążące praktyki i zwyczaje (w przeciwieństwie do wiedzy strony) mogą modyfikować albo wyłączyć wymóg przewidywalności - znajduje on zastosowanie tylko wtedy, gdy strony nie zdecydowały się na odmienną regulację odpowiedzialności odszkodowawczej ${ }^{52}$. Zgodnie z art. 6 CISG, strony mają prawo wyłączyć zastosowanie konwencji albo uchylić bądź zmienić skutki jej postanowień, co wiąże się także z możliwością umownego określenia odpowiedzialności odszkodowawczej ${ }^{53}$.

Oprócz modyfikacji odpowiedzialności odszkodowawczej, z woli stron (przede wszystkim wyrażonej $\mathrm{w}$ postanowieniach umowy), wiążących praktyk albo zwyczajów może też wynikać, że strona posiadała informację o ryzyku związanym z niewykonaniem umowy; w innych przypadkach analiza ogólnego celu umowy albo poszczególnych jej postanowień może wskazywać na to, co powinno być w danej sytuacji przewidywalne. Przykładowo, wskazanie przeznaczenia towarów zgodnie z art. 35 (2) lit. b CISG (względnie zapewnienie dotyczące przydatności danego towaru do określonego celu) może być źródłem wiedzy co do okoliczności mających wpływ na powinność przewidzenia szkody; podobnie jak wskazanie celów zawarcia umowy ${ }^{54}$ lub terminu dostaw ${ }^{55}$; w niektórych przypadkach rozstrzygnięcie przewidywalności szkody możliwe jest przez odwołanie się do INCOTERM RULES ${ }^{56}$.

${ }^{52}$ D. Saidov, Methods..., s. 336-338; zob. np. Orzeczenie Federal District Court [Illinois] (USA), 29.01.2003, (Ajax Tool Works, Inc. v. Can-Eng Manufacturing Ltd.), http://www. cisg.law.pace.edu/cisg/wais/db/cases2/030129u1.html [Dostęp: 27.11.2021 r.]: „It is undisputed that the parties' agreement states that „[Seller] shall not be liable for consequential damages". As discussed above, such limited liability provision is enforceable under the CISG".

${ }^{53}$ L. Gama [Sprawozdawca], CISG..., pkt 1.17: „As regards claims to compensation for the breach of contractual obligations, which are primarily delineated by Article 74 CISG, the parties are free to limit or exclude by agreement both the amount that can be claimed and the circumstances under which damages can be claimed".

Zob. I. Schwenzer, in: Kommentar zum UN-Kaufrecht (CISG), Hrsg. P. Schlechtriem..., s. 1259.

${ }^{54}$ Orzeczenie Multi-Member Court of First Instance of Athens (Grecja), 4505/2009, http://cisgw3.law.pace.edu/cases/094505gr.html [Dostęp: 27.11.2021 r.], [Tłumaczenie: Dionysios P. Flambouras]: „The criterion for the affirmation of subjective foreseeability is the ability to foresee of the „ideal promisor”, i.e., of the prudent and „reasonable” representative of the circle of transactions in which the breaching promisor belongs, also in the light of the purpose of the specific sales contract".

${ }_{55}$ W odniesieniu do ULIS N. Kranz, Die Schadensersatzpflicht nach den Haager Einheitlichen Kaufgesetzen und dem Wiener UN-Kaufrecht, P. Lang, Frankfurt, Bern, New York, Paris, 1989, s. 171.

${ }^{56}$ Incoterms ${ }^{\circledR}$ and the Incoterms ${ }^{\circledR} 2020$ logo are trademarks of ICC. Use of these trademarks does not imply association with, approval of or sponsorship by ICC unless 
Wola strony (ogólny cel umowy, postanowienia umowne), zwyczaje i praktyki badać należy w kontekście określonego momentu (np. jeśli w umowie zawarto postanowienie precyzujące, że za przewidywalne uznać należy szkody „typowe dla określonego regionu i branży”, to kluczowe może być, kiedy umowa została zawarta: „typowym” ryzykiem w czerwcu 2019 r. nie byłby np. gwałtowny wzrost cen określonego produktu, jednak w czerwcu 2020 r., ze względu na restrykcje związane z koronawirusem, wzrost taki może być „typowy”), perspektywy (np. jeśli konieczne jest badanie przewidywalności na podstawie ustalonego w umowie przeznaczenia towarów, konkretna perspektywa strony naruszającej umowę może być kluczowa w ocenie, czy na podstawie określonego przeznaczenia towarów strona naruszająca umowę powinna była rozpoznać określone ryzyko) i przedmiotu (postanowienia umowne dotyczące odpowiedzialności odszkodowawczej mogą odnosić się jedynie do konkretnych typów szkód).

\subsection{Wiedza stron}

Wiedza - podobnie jak inne wspomniane wcześniej czynniki — może warunkować treść stosunku prawnego między stronami. Ponieważ umiejętność przewidywania ściśle związana jest z umiejętnościami poznawczymi danej osoby, wiedza, jaką strona dysponowała w momencie zawierania umowy, może być kluczowa do ustalenia, czy szkoda była przewidywalna ${ }^{57}$. Wynika to wprost $\mathrm{z}$ art. $74 \mathrm{zd}$. 2 CISG: przewidywal-

specifically stated above. The Incoterms ${ }^{\circledR}$ Rules are protected by copyright owned by ICC. Further information on the Incoterms ${ }^{\circledR}$ Rules may be obtained from the ICC website iccwbo.org.

Zob. Orzeczenie Tribunal of International Commercial Arbitration at the Russian Federation Chamber of Commerce and Industry (Rosja), 6.06.2000, 406/1998, http:// www.cisg.law.pace.edu/cases/000606r1.html [Dostęp: 27.11.2021 r.], [Tłumaczenie: Mykhaylo Danylko, Yelena Kalika]: „Regarding the basis of the term C.I.F., Incoterms 1990 provides that the insurance should cover the price stipulated in the contract plus $10 \%$, i.e., a total of $110 \%$. It is commonly known that the mentioned $10 \%$ covers the expected profit of the buyer and is the ordinary amount of profit in the practice of international trade".

${ }^{57}$ D. Saidov, Methods..., s. 334; V. Knapp, in: Commentary on the International Sales Law, eds. C. Bianca, M. Bonell, Giuffrè, Milano, 1987, s. 542; L. Vékás: The Foreseeability..., s. 162; W. Witz, in: International einheitliches Kaufrecht: Praktiker-Kommentar und Vertragsgestaltung zum CISG, Hrsg. W. Witz, H. Salger, M. Lorenz, Deutscher Fachverlag GmbH, Fachmedien Recht und Wirtschaft, Frankfurt, 2016, s. 603; Orzeczenie Multi-Member Court of First Instance of Athens (Grecja), nr 4505/2009, http:// cisgw3.law.pace.edu/cases/094505gr.html [Dostęp: 27.11.2021 r.]; F. Faust, Die Vorhersehbarkeit..., s. 330; D. Saidov, Methods..., s. 334. 
ność bada się „w świetle okoliczności, które znała lub powinna była znać” (ang. „in the light of the facts and matters of which he then knew or ought to have known"). Zgodnie z definicją słownika języka polskiego, wiedza to „ogół wiadomości zdobytych dzięki badaniom, uczeniu się itp.”; to także „zasób informacji z jakiejś dziedziny” albo po prostu „znajomość czegoś"

Badając przewidywalność szkody, kierować należy się nie tylko tym, jaką wiedzę strona posiadała, lecz także tym, jaką wiedzę powinna była posiadać - wyróżnić więc można wiedzę domniemaną oraz wiedzę faktyczną („okoliczności, które znała lub powinna była znać”) ${ }^{59}$. Wykazanie istnienia wiedzy faktycznej bardzo często sprowadzać będzie się do udowodnienia, że strona przeciwna przekazała określoną informację; istnienie wiedzy faktycznej może jednak zostać udowodnione także w inny sposób ${ }^{60}$, np. przez analizę późniejszego postępowania stron. Istnienie wiedzy może być też ustalone w wyniku analizy wcześniejszych relacji pomiędzy stronami ${ }^{61}$.

Badać należy, czy strona posiadała wiedzę albo powinna posiadać wiedzę odnoszącą się do okoliczności mających wpływ na ryzyko powstania szkody określonego rodzaju oraz określonej wysokości; relewant-

Praca kompleksowo podejmująca tematykę wiedzy w CISG M. Fogt, The Knowledge Test Under the CISG - A Global Threefold Distinction of Negligence, Gross Negligence and De Facto Knowledge, „Journal of Law and Commerce” 2016, vol. 34, no. 1.

${ }^{58}$ Internetowy słownik PWN, https://sjp.pwn.pl/sjp/wiedza;2535847 [Dostęp: 27.11.2021 r.].

${ }^{59}$ M. Fogt, The Knowledge..., s. 26; B. Zeller, Damages..., s. 107; D. Saidov, Methods..., s. 334-336.

${ }^{60}$ D. Saidov, Methods..., s. 335.

${ }^{61}$ Zob. Orzeczenie dotyczące ULIS: Orzeczenie Bundesgerichtshof (Niemcy), 24.10.1979, VIII ZR 210/78, https://www.jurion.de/urteile/bgh/1979-10-24/viii-zr-210_78/ [Dostęp: 27.11.2021 r.]: „Soweit dies möglicherweise auch davon abhängig war, ob es sich um erstmalige Schlechtlieferungen durch den Beklagten handelte oder ob bereits vor Januar 1977 der Beklagte an seine Abnehmer mangelhaften Käse geliefert hatte, könnte dies dem Kläger im Hinblick auf die Voraussehbarkeit (Art. 82 Satz 2 EKG) nur dann zugerechnet werden, wenn auch diese früheren Lieferungen durch den Beklagten aus Exporten des Klägers stammten; das aber hat der Beklagte nicht substantiiert behauptet"; Orzeczenie Tribunal of International Commercial Arbitration at the Russian Federation Chamber of Commerce and Industry (Rosja), 23.12.2004, 97/2004 [Tłumaczenie: G. Nuridzhanyan, A. Morari], http://www.cisg.law.pace.edu/cisg/wais/ db/cases2/040528r1.html [Dostęp: 27.11.2021 r.]: „Both parties confirmed during the hearings that they had had long-lasting business relations which fact was reflected in numerous contracts. In these circumstances, the [Seller], as a professional participant of the market of this kind of goods, could not have been unaware of the fact that the [Buyer] is not the consumer of the delivered goods and that it distributes them on the internal market of Russia, that naturally includes transshipment (resale) of the purchased goods". 
na jest wiedza posiadana przez konkretny podmiot w konkretnym czasie. Na przykład czy Jan Nowak posiadał albo otrzymał do 10 kwietnia 2020 r. informację o okolicznościach wskazujących na to, że opóźniona dostawa towaru stwarza ryzyko powstania kosztów magazynowania towaru w wysokości dwukrotnie wyższej niż przeciętne koszty magazynowania towaru na danym obszarze, albo czy Jan Nowak powinien wiedzieć, uwzględniając stan z 10 kwietnia 2020 r., o okolicznościach, które spowodować mogły, że opóźniona dostawa towaru stwarza ryzyko powstania kosztów magazynowania towaru w wysokości dwukrotnie wyższej niż przeciętne koszty magazynowania towaru na danym obszarze.

\section{Obiektywna i subiektywna przewidywalność szkody}

\subsection{Wprowadzenie}

W dalszej części artykułu autor skupi uwagę na odmiennościach dotyczących badania obiektywnej i subiektywnej przewidywalności szkody. Osobliwością obiektywnego testu przewidywalności szkody w porównaniu z testem subiektywnym jest przede wszystkim to, że obiektywna przewidywalność badana jest także przez pryzmat wiedzy domniemanej w odróżnieniu od subiektywnej przewidywalności szkody, dla której znaczenie może mieć jedynie wiedza faktyczna. Ustalenie istnienia faktycznej wiedzy jest kwestią dowodową. Badanie wiedzy jest konieczne szczególnie wtedy, gdy z woli stron, wiążących praktyk, a także zwyczajów nie wynika wprost, co uznać należy za przewidywalne. To, co można domniemywać, badać należy przede wszystkim przez pryzmat tego, jakiego typu (rodzaju) podmiotem jest strona naruszająca umowę. Badając przewidywalność obiektywną, należy określić stan wiedzy (względnie ustalić, czy możliwe jest domniemanie określonej wiedzy), a w dalszej kolejności, czy można domniemywać (domniemanie drugiego stopnia), że strona, posiadając taką wiedzę, powinna była przewidzieć określoną szkodę ${ }^{62}$.

${ }^{62}$ J. Klatka, G. Żmij, w: Konwencja..., s. $618-619$. 


\subsection{Obiektywna przewidywalność szkody}

\subsubsection{Typ (rodzai) podmiotu dopuszczającego się naruszenia umowy}

W większości przypadków, aby ustalić, jaką wiedzę strona powinna posiadać - w szczególności uwzględniając techniczny charakter transakcji zawieranych $\mathrm{w}$ handlu międzynarodowym - kluczowe będzie określenie, jakiego rodzaju podmiotem była strona dopuszczająca się naruszenia ${ }^{63}$, oraz jaki stopień wiedzy posiadałaby racjonalna osoba tego typu. Miara rozsądnej osoby uregulowana jest w przepisach ogólnych CISG, w szczególności w art. 8 CISG. Artykuł 8 (2) CISG traktuje o osobie rozsądnej tego samego rodzaju, w tych samych okolicznościach. Zarówno typ podmiotu, jak i właściwe dla tego typu podmiotu rozsądne rozumowanie muszą być zawsze określone ad casum ${ }^{64}$. Typ albo rodzaj podmiotu rozumieć należy jako abstrakcyjny model rozsądnej osoby tej samej specjalności, działającej na tym samym (względnie podobnym) rynku ${ }^{65}$. To, jakiego typu podmiotem jest strona umowy, wyznacza głównie: branża podmiotu, pozycja na rynku, rodzaj kwalifikacji właściwy dla tej branży, obszar działania podmiotu. Niekonieczna jest znajomość konkretnych kwalifikacji danej osoby ${ }^{66}$.

${ }^{63}$ Odnośnie do osoby rozsądnej w CISG zob.: M. Schmidt-Kessel, in: Kommentar zum UN-Kaufrecht (CISG), Hrsg. P. Schlechtriem..., s. 238; M. Pazdan, w: Konwencja wiedeńska o umowach międzynarodowej sprzedaży towarów: komentarz, red. M. Pazdan..., s. 139.

${ }^{64}$ Orzeczenie Appellate Court Turku (Finlandia), 24.05.2005, S 04/1600 [Tłumaczenie i edycja: S. Kuoppala], http://www.cisg.law.pace.edu/cisg/wais/db/cases2/050524f5. html [Dostęp: 27.11.2021 r.]: „Consequential losses, such as loss of profit and the loss suffered by the buyer as a result of being held liable to a third party are compensable in the light of the foreseeability rule if the seller knew or a reasonable person in the same position and with the same knowledge ought to have known the relevant circumstances influencing the situation"./ "The basic approach is that the foreseeability of the damages is judged objectively by way of referring to a reasonable person in the same circumstance"; Orzeczenie Oberster Gerichtshof (Austria), 4Ob208/12k, 15.01.2013, https://www.ris.bka.gv.at/Dokument.wxe?Abfrage=Justiz\&Dokumentnummer=JJT_20130115_OGH0002_0040OB00208_12K0000_000 [Dostęp: 27.11.2021 r.]: „Der Schüldner muss mit den Folgen rechnen, die eine verständige Person in seiner Lage angesichts der konkreten Fallumstände vorausgesehen hätte”.

${ }_{65}$ M. Pazdan, w: Konwencja wiedeńska o umowach międzynarodowej sprzedaży towarów: komentarz, red. M. Pazdan..., s. 139.

${ }^{66}$ Częściowo odmienne stanowisko Orzeczenie Arbitration Award of Tribunal of International Commercial Arbitration at the Russian Federation Chamber of Commerce and Industry (Russia), 12.03.1996, Arbitration proceeding 166/1995, http://www.cisg. law.pace.edu/cisg/wais/db/cases2/960312r1.html [Dostęp: 27.11.2021 r.], [Tłumaczenie: M. Danylko, Edycja: D. Saidov]: „In the Tribunal's opinion, the [seller]'s experience in 
W stosunku do umów regulowanych przez CISG należy założyć, że każda ze stron jest przedsiębiorcą ${ }^{67}$ — przyjąć więc można miarę rozsądnego profesjonalisty ${ }^{68}$. Sugeruje się także miarę ostrożnego i rozsądnego reprezentanta określonej branży ${ }^{69}$. W niektórych przypadkach można zatem domniemywać istnienie specjalistycznej wiedzy (ang. „specialized skills or knowledge the person has for the specific type of trade"70). Pozycja rynkowa podmiotu również winna być uwzględniana ${ }^{71}$. Moż-

business and commercial activity allowed him not only to foresee the fact that the [buyer] would suffer loss as a result of the breach of the contract, but also the possibility to avoid it".

${ }^{67}$ CISG znajduje zastosowanie tylko do umów zawieranych w obrocie profesjonalnym; może znaleźć zastosowanie do umów zawieranych z konsumentem jedynie w szczególnych wypadkach: Art. 2 (a): „This Convention does not apply to sales: of goods bought for personal, family or household use, unless the seller, at any time before or at the conclusion of the contract, neither knew nor ought to have known that the goods were bought for any such use".

68 Orzeczenie Cour De Cassation (Francja), 17.02.2015, 12-29550 13-18956 13-20230, https://www.legifrance.gouv.fr/affichJuriJudi.do?idTexte=JURITEXT000030270329 [Dostęp: 27.11.2021 r.]: „et que cette documentation, établie par les soins de la société Gabo, ne permet pas de conclure à la certitude de l'existence et de l'étendue du préjudice subi par celle-ci comme conséquence de l'inexécution de la société Dupiré Invicta industrie, pas plus qu'à la prévisibilité du préjudice qu'un professionnel raisonnable pouvait faire sur les conséquences d'une éventuelle inexécution telle qu'elle résulte du cours ordinaire des choses et des circonstances particulières du contrat qui est exigée par l'article 74 de la Convention de Vienne".

${ }^{69}$ Orzeczenie Multi-Member Court of First Instance of Athens (Grecja) 4505/2009 (Bullet-proof vest case), http://cisgw3.law.pace.edu/cases/094505gr.html [Dostęp: 27.11.2021 r.].

${ }^{70}$ Orzeczenie Multi-Member Court of First Instance of Athens (Grecja) 4505/2009 (Bullet-proof vest case), http://cisgw3.law.pace.edu/cases/094505gr.html [Tłumaczenie i edycja: D. Flambouras], [Dostęp: 27.11.2021 r.].

W stosunku do ULIS N. Kranz, Die Schadensersatzpflicht..., s. 172.

${ }^{71}$ Orzeczenie SN (Polska), 20.01.2015, V CSK 254/14, http://www.sn.pl/orzecznictwo/ SitePages/Baza_orzeczen.aspx?ItemSID=17564-57a0abe2-a73c-441d-9691-b79a0c36be5 c\&ListName $=$ Orzeczenia3\&Sygnatura $=\mathrm{V}+\mathrm{CSK}+254 \% 2 \mathrm{f} 14$ [Dostęp: 27.11 .2021 r.]: „Odwołując się do pozycji rynkowej pozwanej, która w owym okresie zapewniała 15\% podaży koksu na rynku, wskazał, że biegły J.L. doszedł do wniosku, iż pozwana miała w chwili zawierania umowy wiedzę o aktualnej sytuacji gospodarczej na świecie w zakresie handlu koksem, a to pozwalało jej na poznanie trendów podaży i ich wpływu na cenę i dlatego można było założyć, że podwyżka cen koksu nastąpi o dalsze 20\%”.

Orzeczenie Audiencia Provincial De Madrid (Hiszpania), 10.03.2010, 759/2008, https://docplayer.es/5548241-Audiencia-provincial-de-madrid-10-marzo-2009-fuentearanzadi-westlaw.html [Dostęp: 27.11.2021 r.]: „Simplemente porque conociendo Vinos y Bodegas, S.A. la adición de ácido benzoico al vino suministrado, y conociendo como comerciante del sector la improcedencia de añadir esa sustancia al vino, resultaba del todo previsible la imposibilidad de su comercialización a terceros, y el consiguiente alcance de la pérdida a sufrir por Rexim, que no tenía la condición de consumidor final sino de co- 
na także wziąć pod uwagę to, czy strona działała już na określonym rynku $^{72}$.

\subsubsection{Powinność przewidywania szkody}

Obiektywna przewidywalność szkody określana jest przez pryzmat powinności przewidywania szkody. Strona naruszająca umowę odpowiada jedynie za szkodę, którą powinna była wziąć pod uwagę, a nie za tę, którą mogła wziąć pod uwagę. Zakres tego, co osoba rozsądna może przewidywać, jest znacznie szerszy od tego, co osoba ta powinna przewidywać. I tak, można przewidywać, że ktoś zostanie uderzony piorunem, ponieważ znane są przypadki porażenia człowieka piorunem. Kierując się ogólnym stanem wiedzy oraz zdolnościami poznawczymi osoby rozsądnej, można dojść do wniosku, że ryzyko takie istnieje, nawet jeśli jest bardzo niewielkie. Rozumując w ten sposób, można przewidzieć praktycznie wszystko. „Skrajny pesymista” będzie uwzględniał takie ryzyko, jednakże pozostaje to bez znaczenia. Mimo możliwości przewidzenia takiego zdarzenia, strona nie ma - z punktu widzenia racjonalnej osoby — takiej powinności. Na gruncie art. 74 zd. 2 CISG powinność przewidywania od możliwości przewidywania odróżniana jest ad casum. Rozważyć warto relację między prawdopodobieństwem wystąpienia szkody a jej przewidywalnością oraz relację między proporcjonalnością wysokości szkody i wartości transakcji a przewidywalnością szkody.

Konieczności wykazania, że szkoda jest prawdopodobna (a więc, że wystąpi w większości przypadków) nie można uznać za przesłankę przyznania za nią odszkodowania. Utożsamianie szkody przewidywalnej ze szkodą prawdopodobną wiązałoby się z istotnymi problemami dowodowymi $^{73}$ oraz mogłoby prowadzić do niedopuszczalnych rezultatów - nie-

merciante, en cuya condición orientaba la adquisición a la reventa a terceros, con la consiguiente obtención de un beneficio derivado del margen comercial aplicado sobre el precio de esa reventa. La defectuosa calidad del vino destinado por Rexim a la comercialización a terceros, evidencia la previsible causación de un lucro cesante".

72 Orzeczenie SA w Szczecinie (Polska), 7.02.2013, I ACa 637/12, http://orzeczenia. szczecin.sa.gov.pl/content/\$N/155500000000503_I_ACa_000637_2012_Uz_2013-0207_001 [Dostęp: 27.11.2021 r.]: „Nie budzi też wątpliwości, że taki skutek strona pozwana (naruszająca umowę) mogła przewidzieć, pozwana zawierała już bowiem kontrakty z przedsiębiorcami z D., ponadto umowa wyraźnie określała przedmiot umowy jako pelet nie zawierający substancji sklejających i trujących"; Orzeczenie Tribunal of International Commercial Arbitration at the Russian Federation Chamber of Commerce and Industry (Rosja), 23.12.2004, 97/2004 [Tłumaczenie: G. Nuridzhanyan, A. Morari], http://www.cisg.law.pace.edu/cisg/wais/db/cases2/040528r1.html [Dostęp: 27.11.2021 r.].

${ }^{73}$ Por. U. Steinmetzler, Recht und Ökonomie der Grundstrukturen des Leistungsstörungsrechts im UN-Kaufrecht, Schriftenreihe Studien zur Rechtswissenschaft 79, 
dopuszczalne jest bowiem wprowadzenie „granicy prawdopodobieństwa” $(50 \% \text { szansy wystąpienia szkody })^{74}$, która stanowiłaby granicę pomiędzy szkodą przewidywalną a nieprzewidywalną. Mimo wszystko prawdopodobieństwo wystąpienia szkody (określane na skali od 0\% do 100\% szansy wystąpienia) nie jest bez znaczenia ${ }^{75}$. Prawdopodobieństwo wystąpienia szkody bywa czasami uwzględniane w orzecznictwie ${ }^{76}$. Podmioty profesjonalne szacują wtedy ryzyko, usiłując wyliczyć prawdopodobieństwo wystąpienia określonych kosztów (a więc także ryzyka wyrządzenia kontrahentowi szkody) ${ }^{77}$. Prawdopodobieństwo i przewidywalność szkody nie są kategoriami tożsamymi, zazębiają się jednak w pewnym stopniu. Brak podstaw do uznania, że szkoda nieprawdopodobna zawsze będzie szkodą nieprzewidywalną (np. ze względu na szczególną wiedzę strony, na postanowienia umowne itd.), jednakże szkody prawdopodobne będą tė̇ często przewidywalne. Można zatem z całą pewnością stwierdzić, że im wyższe jest prawdopodobieństwo wystąpienia szkody, „tym bardziej” przewidywalna jest ta szkoda, nawet jeśli niedopuszczalne i niecelowe jest wyznaczanie konkretnej granicy prawdopodobieństwa. Wysokie prawdopodobieństwo (np. powyżej 50\%) wystąpienia szkody nie jest więc przesłanką uznania szkody za przewidywalną; prawdopodobieństwo wystąpienia szkody (określane w skali od 0\% do 100\%) powinno być jednak

Kovač, Hamburg, 2001, s. 274. Przytoczony autor argumentuje, że matematyczne obliczenie przewidywalności nie jest możliwe.

74 F. Faust, Die Vorhersehbarkeit..., s. 33-34.

75 Zob. J. Heilmann, Mängelgewährleistung im UN-Kaufrecht: Voraussetzungen und Rechtsfolgen im Vergleich zum deutschen internen Kaufrecht und zu den Haager Einheitlichen Kaufgesetze, Duncker \& Humblot, Berlin, 1994, s. 578; W. Witz, in: International einheitliches Kaufrecht: Praktiker-Kommentar und Vertragsgestaltung zum CISG, Hrsg. W. Witz..., s. 603-604; Por. U. Magnus, Europäische Kaufrechtsvereinheitlichung, „Rabels Zeitschrift für ausländisches und internationales Privatrecht” 1981, Nr. 45, s. 154 - odnośnie do Konwencji ULIS.

${ }^{76}$ Por. Orzeczenie Oberster Gerichtshof (Austria), 7 Ob 301/01t, 14.01.2002, http:// www.unilex.info/case.cfm?pid=1\&do=case\&id=858\&step=FullText [Dostęp: 27.11.2021 r.]: „Auch Mangelfolgeschäden sind, soweit es sich um Vermögensschäden handelt, wie bereits erwähnt, nach dem UN-Kaufrecht grundsätzlich ersatzfähig, wenn der eingetretene Schaden bei Vertragsschluss als hinreichend wahrscheinliche Folge erkannt werden konnte".

Oberlandersgericht Wien (Austria) 1 R 192/16m, 23.01.2017, https://rdb.manz.at/ document/ris.just.JJT_20170123_OLG0009_00100R00192_16M0000_000［Dostęp: 27.11.2021 r.]; Orzeczenie Federal District Court [New York] (USA), 23.08.2006, (TeeVee Tunes, Inc. et al v. Gerhard Schubert GmbH): „CISG provides that damages for breach include lost profits, subject only to the familiar limitation that the breaching party must have foreseen, or should have foreseen, the loss as a probable consequence".

${ }_{77}$ M. Eisenberg, Probability and Chance in Contract Law, „UCLA Law Review” 1998, no. 45, s. 1073. 
uwzględniane podczas badania, czy strona powinna była przewidywać szkodę; jeśli możliwe jest jego oszacowanie.

Badając, czy strona powinna była uwzględnić określone ryzyko, posiłkować powinno się również relacją pomiędzy wartością transakcji (ceną towarów względnie wartością towarów) a wartością wyrządzonej szkody. W systemach prawnych Common law zależność ta nazywana jest disproportionate compensation albo po prostu disproportionality ${ }^{78}$. Proporcja ta jest okolicznością znaną obu stronom umowy; rozsądne jest, że kalkulacje ryzyka strony będą przeprowadzać przez pryzmat tejże wartości. Jest ona więc związana z przewidywalnością szkody ${ }^{79}$, chociaż podobnie jak w przypadku prawdopodobieństwa wystąpienia szkody — nie może stanowić samodzielnej i jedynej podstawy rozstrzygnięcia problemu przewidywalności.

\subsection{Subiektywna przewidywalność szkody}

Badając subiektywną przewidywalność, nie jest konieczne badanie domniemanej wiedzy strony, a co za tym idzie, nie jest konieczna analiza okoliczności i rodzaju podmiotu, w celu ustalenia, jaką wiedzę strona powinna posiadać i jak mogła ona wpłynąć na przewidywalność.

Wykazanie, że strona przewidziała faktycznie określoną szkodę jest przede wszystkim kwestią dowodową. Sprowadzać się będzie często do wskazania, że określone ryzyko było wspomniane w umowie, wynika wprost z praktyki wiążącej strony albo ze zwyczaju bądź też stosowna informacja została przekazana przez stronę przeciwną na etapie negocjacji umowy.

Subiektywna przewidywalność szkody może jedynie rozszerzyć odpowiedzialność odszkodowawczą strony ${ }^{80}$. Faktyczne nieprzewidywanie szkody nie może być zatem użyte w celu wykazania, że strona nie powinna odpowiadać za określoną szkodę ${ }^{81}$. Uwzględnianie subiektywnej

${ }^{78}$ Zob. Restatement (Second) of Contract (1979) § 351 (3): „A court may limit damages for foreseeable loss by excluding recovery for loss of profits, by allowing recovery only for loss incurred in reliance, or otherwise if it concludes that in the circumstances justice so requires in order to avoid disproportionate compensation"; L. Garvin, Disproportionality and the Law of Consequential Damages: Default Theory and Cognitive Reality, „Ohio State Law Journal” 1998, vol. 59, no. 2, s. 342.

${ }_{79}$ Por. L. Garvin, Disproportionality..., s. 348.

80 E. Demir, Die Schadensersatzregelung im UN-Kaufrecht: Übereinkommen der Vereinten Nationen über Verträge über den internationalen Warenkauf (CISG), Stämpfli Verlag, Bern, 2015, s. 159.

${ }^{81}$ K. Cohen, Achieving a Uniform Law Governing International Sales: Conforming the Damages Provisions of the United Nations Convention on Contracts for the Interna- 
przewidywalności szkody w myśl przepisów CISG oznacza, że korzystne może być dla stron przekazywanie stosownych informacji na temat potencjalnego ryzyka. W niektórych sytuacjach przekazanie stosownej informacji będzie konieczne, aby uzyskać odszkodowanie za określoną szkodę: strona przeciwna - ze względu na nietypową sytuację kontrahenta - nie będzie miała możliwości pozyskania stosownej informacji z innych źródeł ${ }^{82}$. Przekazywanie informacji przez strony umowy przyczynia się do transparentności relacji, jednocześnie zaś - z perspektywy profesjonalisty - istotne jest zachowanie balansu ${ }^{83}$. „Straszenie” kontrahenta wszystkimi potencjalnymi szkodami związanymi z niewykonaniem kontraktu może co prawda zapewnić uzyskanie odszkodowania za wszystkie szkody, jednak działanie to może zniechęcić stronę do zawierania umowy albo przynajmniej do zawarcia umowy na określonych warunkach ${ }^{84}$.

Strona musi nie tylko przewidzieć ryzyko wystąpienia szkody określonego typu, lecz także jej wysokości. Nie jest oczywiście konieczne przekazanie informacji o możliwości wystąpienia szkody i dokładnej jej wysokości - ta byłaby bowiem niemożliwa do wyliczenia w momencie zawierania umowy. Stosowna informacja od kontrahenta powinna jednak umożliwić nie tylko uświadomienie sobie zagrożenia wystąpienia szkody określonego rodzaju, lecz także przynajmniej przybliżonych konsekwencji finansowych takiej szkody.

\section{Podsumowanie}

Jednolita wykładnia art. 74 zd. 2 CISG ma kluczowe znaczenie dla prawidłowego funkcjonowania modelu odpowiedzialności odszkodowawczej w przepisach CISG. Warunkuje ona też bezpośrednio sposób postrzegania tej Konwencji oraz ma wpływ na ocenę, czy zasadne jest wyłączenie jej zastosowanie przez strony umowy.

tional Sale of Goods and the Uniform Commercial Code, „University of Pennsylvania Journal of International Economic Law” 2005, no. 26, s. 611-612.

${ }^{82}$ Orzeczenie Oberlandesgericht Bamberg (Niemcy), 13.01.1999, 3 U 83/98, http://www.unilex.info/case.cfm?pid=1\&do=case\&id=504\&step=FullText [Dostęp: 27.11 . 2021 r.]: „Schäden, die durch die besonderen Verhältnisse des Gläubigers, die von ihm getroffenen Dispositionen und wirtschaftlichen Rahmenbedingungen beeinflußt werden, sind im Allgemeinen nur zu ersetzen, wenn sie dem Schuldner bekannt waren".

${ }^{83}$ Por. D. Saidov, The law..., s. 120-122.

${ }^{84}$ Por. D. Saidov, The law..., s. $120-122$. 
Osiągnięcie tego celu jest możliwe przede wszystkim dzięki stosowaniu konkretnie sformułowanego sposobu badania przewidywalności szkody zgodnie $\mathrm{z}$ art. 74 zd. 2 CISG $^{85}$, który zapewni precyzyjne badanie szczegółowych zagadnień związanych $\mathrm{z}$ przewidywalnością szkody, zachowanie „balansu” pomiędzy luzem decyzyjnym a pewnością prawa, a także dzięki któremu zmniejszone zostanie ryzyko odwołania się do ogólnego rozumienia przewidywalności szkody oraz „posiłkowania się” wiedzą na temat krajowych ograniczeń odpowiedzialności odszkodowawczej.

\section{Bibliografia}

Ackermann T., Adäquanz und Vorhersehbarkeitsregel: ein transparenter methodischer Ansatz, dargestellt am Beispiel des schweizerischen Haftpflicht- und Vertragsrechts, des Wiener Kaufrechts und des schweizerischen Sozialversicherungsrechts, Haupt Verlag, Bern, 2001.

Bianca C., Bonell M., Commentary on the International Sales Law, Giuffrè, Milano, 1987.

Brunner Ch., UN-Kaufrecht - CISG: Kommentar zum Übereinkommen der Vereinten Nationen über Verträge über den internationalen Warenkauf von 1980 - Unter Berücksichtigung der Schnittstellen zum internen Schweizer Recht, Stämpfli Verlag, Bern, 2014.

Cohen K., Achieving a Uniform Law Governing International Sales: Conforming the Damages Provisions of the United Nations Convention on Contracts for the International Sale of Goods and the Uniform Commercial Code, „University of Pennsylvania Journal of International Economic Law" 2005, no. 26.

Demir E., Die Schadensersatzregelung im UN-Kaufrecht: Übereinkommen der Vereinten Nationen über Verträge über den internationalen Warenkauf (CISG), Stämpfli Verlag, Bern, 2015.

Dölle H., Kommentar Zum Einheitlichen Kaufrecht, C.H. Beck, München, 1976.

Durbas M., Przewidywalność szkody jako przestanka odpowiedzialności odszkodowawczej na gruncie Konwencji wiedeńskiej — glosa - V CSK 91/11, „Monitor Prawniczy” 2014, nr 5.

${ }^{85}$ Wpływ na prawidłową aplikację art. 74 zd. 2 CISG może mieć również to, czy będzie ona badana przez sędziego, czy przez arbitra, zob. M. Kochanowski, Foreseeability of Damage under CISG Applied in International Arbitration. New Solutions to Old Problems?, in: Austrian Yearbook on International Arbitration. 2020, eds. Christian Klausegger et al., MANZ, Verlag Wien, Wien, 2020. 
Ehlers A., Establishing a Uniform Interpretation of the CISG: A Case Study of Article 74, „Nordic Journal of Commercial Law” 2013, no. 2.

Eisenberg M., Probability and Chance in Contract Law, „UCLA Law Review” 1998, vol. 45.

Faust F., Die Vorhersehbarkeit des Schadens gemäß Art. 74 Satz 2 UN-Kaufrecht (CISG), Mohr Siebeck, Tübingen, 1996.

Felemegas J., An international approach to the interpretation of the United Nations Convention on Contracts for the International Sale of Goods (1980) as uniform sales law, Cambridge University Press, Cambridge, New York, 2007.

Ferrari F., Comparative Ruminations on the Foreseeability of Damages in Contract Law, „Louisiana Law Review” 1993, vol. 53, no. 4.

Fogt M., The Knowledge Test Under the CISG - A Global Threefold Distinction of Negligence, Gross Negligence and De Facto Knowledge. „Journal of Law and Commerce" 2016, vol. 34, no. 1.

Gama L. [Sprawozdawca], CISG Advisory Council Opinion No. 17 Limitation and Exclusion Clauses in CISG Contracts, Adopted by the CISG-AC following its 21st meeting in Bogotá, Colombia, on 16 October 2015, http://cisgac. com/opinion-17/.

Gotanda J. [Sprawozdawca], CISG advisory council opinion no. 6: Calculation of Damages under CISG Article 74, Adopted by the CISG-AC at its Spring 2006 meeting in Stockholm, Sweden, 2006, http://cisgw3.law.pace.edu/cisg/ CISG-AC-op6.html.

Heilmann J., Mängelgewährleistung im UN-Kaufrecht: Voraussetzungen und Rechtsfolgen im Vergleich zum deutschen internen Kaufrecht und zu den Haager Einheitlichen Kaufgesetze, Duncker \& Humblot, Berlin, 1994.

Herber R., Czerwenka B, Internationales Kaufrecht: Kommentar zu dem Übereinkommen der Vereinten Nationen vom 11. April 1980 über Verträge über den Internationalen Warenkauf, Hrsg. R. Herber, B. Czerwenka, C.H. Beck, München, 1991.

Heuzé V., La Vente Internationale de Marchandises: Droit Uniforme, L.G.D.J, Paris, 2000.

Honnold J., Documentary history of the uniform law for international sales: the studies, deliberations, and decisions that led to the 1980 United Nations Convention with introductions and explanations, Kluwer Law and Taxation Publishers, Deventer, 1989.

Honsell H., Kommentar zum UN-Kaufrecht: Übereinkommen der Vereinten Nationen über Verträge über den Internationalen Warenkauf (CISG), Springer, Berlin, 2008.

Huber U., Der Uncitral-Entwurf Eines Übereinkommens über Internationale Warenkaufverträge, „Rabels Zeitschrift für ausländisches und internationales Privatrecht” 1979, vol. 43, Nr. 3.

Karollus M., UN-Kaufrecht: Eine Systematische Darstellung für Studium und Praxis, Springer, Wien, New York, 1991.

Keil A., Die Haftungsbefreiung des Schuldners im UN-Kaufrecht im Vergleich mit dem deutschen und US-amerikanischen Recht, P. Lang, Köln, 1994. 
Koch A., Zwiazek przyczynowy jako podstawa odpowiedzialności odszkodowawczej w prawie cywilnym, Państwowe Wydawnictwo Naukowe, Warszawa, 1975.

Kochanowski M., Foreseeability of Damage under CISG Applied in International Arbitration. New Solutions to Old Problems?, in: Austrian Yearbook on International Arbitration. 2020, eds. Christian Klausegger et al., MANZ Verlag Wien, Wien, 2020.

Kranz N., Die Schadensersatzpflicht nach den Haager Einheitlichen Kaufgesetzen und dem Wiener UN-Kaufrecht, P. Lang, Frankfurt, Bern, New York, Paris, 1989.

Machnikowski P., CISG in Polish case law, „Internationales Handelsrecht” 2018, Nr. 5.

Magnus U., Europäische Kaufrechtsvereinheitlichung, „Rabels Zeitschrift für ausländisches und internationales Privatrecht" 1981, Nr. 45.

Magnus U., Wiener UN-Kaufrecht (CISG). J. von Staudingers Kommentar zum Bürgerlichen Gesetzbuch mit Einführungsgesetz und Nebengesetzen Wiener UN-Kaufrecht (CISG), Sellier - de Gruyter, Berlin, 2018.

Napierała J., Odpowiedzialność eksportera $i$ importera za naruszenie umowy międzynarodowej sprzedaży towarów, ABC, Warszawa, 1998`.

Osajda K., Kodeks cywilny. Komentarz, C.H. Beck, Warszawa, 2019.

Pazdan M., Konwencja wiedeńska o umowach międzynarodowej sprzedaży towarów: komentarz, Zakamycze, Kraków, 2001.

Piltz B., Internationales Kaufrecht: Das UN-Kaufrecht in Praxisorientierter Darstellung, C.H. Beck, München, 2008.

Rabel E., Das Recht des Warenkaufs. Eine rechtsvergleichende Darstellung 1. Band, Walter de Gruyter \& Co., Berlin, 1964.

Rajski J., Jednolite prawo międzynarodowej sprzedaży towarów, „Przegląd Prawa Handlowego" 1996, nr 3.

Saidov D., Methods of Limiting Damages under the Vienna Convention on Contracts for the International Sale of Goods, „Pace International Law Review” 2002 , vol. 14 , no. 2.

Saidov D., The law of damages in international sales: the CISG and other international instruments, Hart Publishing, Oxford, Portland, 2008.

Schlechtriem P., Schwenzer I., Schroeter U., Kommentar zum UN-Kaufrecht (CISG), C.H. Beck, München, 2019.

Schneider E., Measuring Damages under the CISG - Article 74 of the United Nations Convention on Contracts for the International Sale of Goods, „Pace International Law Review" 1997, vol. 9, no. 1.

Steinmetzler U., Recht und Ökonomie der Grundstrukturen des Leistungsstörungsrechts im UN-Kaufrecht, Schriftenreihe Studien zur Rechtswissenschaft 79, Kovač, Hamburg, 2001.

Treitel G.H., Remedies for Breach of Contract. A comparative account, Clarendon Press, Oxford University Press, Oxford, 1988.

Vékás L., The Foreseeability Doctrine in Contractual Damage Cases, „Acta Juridica Hungarica" 2002, vol. 43, no. 1-2. 
Weitnauer H., Nichtvoraussenhbarkeit Eines Schadens Nach Art. 82 S. 2 Des Einheitlichen Gesetzes Über Den Internationales Kauf Beweglichen Sachen, „Praxis des Internationalen Privat- und Verfahrensrechts” 1981, vol. 4, Nr. 1.

Witz W., Salger H., Lorenz M., International einheitliches Kaufrecht: Praktiker-Kommentar und Vertragsgestaltung zum CISG, Deutscher Fachverlag GmbH, Fachmedien Recht und Wirtschaft, Frankfurt, 2016.

Zeller B., Damages under the Convention on Contracts for the International Sale of Goods, Oceana Publications Inc, Oxford, 2018. 